\title{
Letter
}

\section{Tributyltin induces cell cycle arrest at G1 phase in the yeast Saccharomyces cerevisiae}

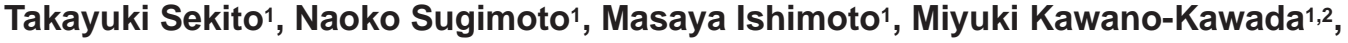 \\ Koichi Akiyama1,2, Sogo Nishimoto ${ }^{3}$, Takuya Sugahara ${ }^{1}$ and Yoshimi Kakinuma1,2 \\ ${ }^{1}$ Faculty of Agriculture, Ehime University, Tarumi 3-5-7, Matsuyama 790-8566, Japan \\ 2Integrated Center for Sciences (INCS), Ehime University, Tarumi 3-5-7, Matsuyama 790-8566, Japan \\ ${ }^{3}$ Center for Marine Environmental Studies (CMES), Ehime University, 2-5 Bunkyo-cho, Matsuyama, \\ Ehime 790-8577, Japan
}

(Received November 10, 2013; Accepted January 16, 2014)

\begin{abstract}
Tributyltin (TBT) has long been recognized as a major environmental pollutant that can cause significant damage to the cellular functions as well as disruption of endocrine homeostasis. TBT induces apoptosis accompanied by production of reactive oxygen species (ROS) in mammalian and yeast cells. We observed that the budding yeast cells exposed to this compound at low concentrations exhibited cell growth arrest, but not cell death. Flow cytometric analysis of yeast cells without synchronization and morphological assessment of cells synchronized at $\mathrm{M}$ phase by nocodazole treatment indicated that TBT-exposed Saccharomyces cerevisiae cells were arrested at G1 phase of the cell cycle. This arrest was recovered by the addition of $\mathrm{N}$-acetylcysteine, suggesting the involvement of ROS production by TBT. This is the first study to evaluate the action of TBT on cell cycle events.
\end{abstract}

Key words: Tributyltin, Cell cycle, Reactive oxygen species, Saccharomyces cerevisiae

\section{INTRODUCTION}

Tributyltin (TBT) has been widely used as a wood preservative and an antifouling agent in paints for marine vessels. It is also used as a biocide in textiles, brewing, paper mills, and in power plant cooling systems, and as a stabilizer of polyvinylchloride. TBT and its degradation products will persist in aquatic sediments causing widespread contamination of the environment (Iwata et al., 1995; Tanabe, 1999; Antizar-Ladislao, 2008). The use of TBT, which is regulated internationally, can cause high toxicity, resulting in undesirable effects in non-target marine organisms, such as increase in shell malformation, imposex, and population decline in gastropods (Beaumont and Budd, 1984; Alzieu et al., 1986; Dyrynda, 1992; Davies et al., 1997). TBT is also toxic to mammalian cells (Antizar-Ladislao, 2008; Kotake, 2012). Many studies have demonstrated that TBT-induced apoptosis on various cell types such as thymocytes, neuronal cells, and hepatocytes (Aw et al., 1990; Raffray and Cohen, 1993; Thompson et al., 1996; Reader et al., 1999; Kawanishi et al., 1999). It has been suggested that TBT- dependent apoptosis is mediated by a change in the intracellular calcium levels followed by the production of reactive oxygen species (ROS) (Gennari et al., 2000).

TBT is harmful to eukaryotic microorganisms. Studies were performed with yeast such as Debaryomyces hansenii (Oliver et al., 1989), Rhodotorula ferulica (Veiga et al., 1997), and Candida maltosa (White and Tobin, 2004), and TBT-induced cellular potassium leakage and a defect in ATP production were reported in these studies. Based on the availability of genetic tools and homology to higher eukaryotes, Saccharomyces cerevisiae can be used to understand the cell toxicity induced by TBT exposure. As for mammalian cells, TBT induces apoptosis-like cell death in S. cerevisiae, possibly downstream of the ROS production (Chahomchuen et al., 2009a). In a previous study, we also discovered that treating $S$. cerevisiae with a low dose of TBT inhibited cell growth, but did not cause cell death (Chahomchuen et al., 2009a). In this study, we further examined the effects of TBT on cell cycle progression of $S$. cerevisiae.

Correspondence: Yoshimi Kakinuma (E-mail: ykaki@agr.ehime-u.ac.jp) 


\section{MATERIALS AND METHODS}

\section{Yeast strains and growth conditions}

The strain used in this study was $S$. cerevisiae BY4741 (MATa, his3- $\Delta 1$, leu2- $\Delta 0$, ura3- $\Delta 0$, met15- $\Delta 0$ ) and its derivative STY4576 (BY4741, SIC1-MYC9::KanMX). Yeast cells grown in YPD (1\% yeast extract, $2 \%$ peptone, $2 \%$ glucose) at $30^{\circ} \mathrm{C}$ to $\mathrm{OD}_{660}=1.0-1.5$ were diluted to $\mathrm{OD}_{660}=0.6$ in fresh YPD containing TBT and/or $N$-acetylcysteine (NAC) to concentrations specified in the figure legends, and the cultivation further proceeded. Dimethyl sulfoxide $\left(\mathrm{Me}_{2} \mathrm{SO}\right)$ was added to $0.1 \%(\mathrm{v} / \mathrm{v})$ in the control culture. $\mathrm{OD}_{660}$ of the cultures was measured at each time point to draw the growth curve. To determine cell viability, cells were collected before addition, or $2 \mathrm{hr}, 6 \mathrm{hr}, 12$ $\mathrm{hr}$, and $24 \mathrm{hr}$ after addition of TBT or $\mathrm{Me}_{2} \mathrm{SO}$, and equal numbers of cells for each treatment (determined after reading $\mathrm{OD}_{660}$ ) were spread on YPD plates. Plates were incubated at $30^{\circ} \mathrm{C}$ for 3 days before counting the number of colonies to calculate cell viability.

\section{Flow cytometry and cell cycle manipulations}

In experiment with asynchronous cultures, TBT $(5 \mu \mathrm{M})$ or $\mathrm{Me}_{2} \mathrm{SO}$ was added to cultures in YPD and samples were collected at the specified time intervals. Flow cytometric analysis was performed as described previously (Haase and Lew, 1997) by using FACScalibur with CellQuest (BD Biosciences, San Jose, CA, USA). Briefly, cells were fixed in $70 \%$ ethanol, washed once with water, and incubated for $1 \mathrm{hr}$, at $37^{\circ} \mathrm{C}$, with $2 \mathrm{mg} / \mathrm{ml}$ boiled RNase A (Sigma-Aldrich, St. Louis, MO, USA) in $50 \mathrm{mM}$ Tris-HCl, pH 7.5. Cells were then resuspended in a $55 \mathrm{mM} \mathrm{HCl}$ solution containing $5 \mathrm{mg} / \mathrm{ml}$ pepsin (Sigma-Aldrich), and incubated for $30-60 \mathrm{~min}$ at $37^{\circ} \mathrm{C}$. This was followed by a $1 \mathrm{hr}$ incubation at room temperature with $75 \mathrm{mM}$ propidium iodide (PI) (Sigma-Aldrich) dissolved in $180 \mathrm{mM} \mathrm{NaCl}, 70 \mathrm{mM} \mathrm{MgCl}, 100 \mathrm{mM}$ Tris-HCl, pH 7.5 ( $1 \times$ PI solution). After PI staining, 1 $\times 10^{6}$ cells were placed in a $6-\mathrm{ml}$ polystyrene tube (BD Biosciences) containing $0.1 \times$ PI solution diluted in 50 $\mathrm{mM}$ Tris, $\mathrm{pH} 7.5$, lightly sonicated, and analyzed.

For cell cycle synchronization at $\mathrm{M}$ phase, the yeast cells were cultured in the presence of $15 \mu \mathrm{g} / \mathrm{ml}$ nocodazole for $2 \mathrm{hr}$ and washed three times with sterile water. Cells were then released into YPD containing TBT $(5 \mu \mathrm{M})$ or $\mathrm{Me}_{2} \mathrm{SO}$, cultured at $30^{\circ} \mathrm{C}$, and collected at every $20 \mathrm{~min}$ for microscopic observation of the bud size.

\section{Morphological estimation of cell cycle phase distribution}

Images of cells were captured by Olympus IX71 microscope and morphology of each cells were analyzed by Metamorph software (Molecular Devices, Sunnyvale, CA, USA). Bud size was assigned by dividing the bud length by the length of mother cells. Cells with a ratio of 0 were classified as unbudded; cells were categorized into small bud when the ratio was between 0 and 0.6 , and large bud when the ratio was higher than 0.6.

\section{Western blot analysis}

Whole cell extracts were prepared according to a trichloroacetic acid precipitation method (Chahomchuen et al., 2009b). Sic1-Myc ${ }^{9}$ and phosphoglycerate kinase (PGK) were detected by anti-Myc 9E10 (Babco, Richmond, CA, USA) and anti-PGK 22C5 (Molecular Probes, Eugene, OR, USA) monoclonal antibodies, respectively. Primary antibodies were detected using HRP-conjugated secondary antibody and ECL detection system (GE Healthcare, Little Chalfont, Buckinghamshire, UK). Western gel images were quantified by densitometry using Image J software (National Institutes of Health, Bethesda, MD, USA).

\section{RESULTS AND DISCUSSION}

In the previous study (Chahomchuen et al., 2009a), we found that cells maintained the viability after treatment with low dose $(5 \mu \mathrm{M})$ of TBT for $2 \mathrm{hr}$ and cell proliferation was completely stopped during the treatment. To examine the effect of prolonged exposure to TBT on cell viability, S. cerevisiae BY4741 strain was grown in YPD medium in the presence of different concentrations $(0,1$, $2.5,5$ and $15 \mu \mathrm{M})$ of TBT, and the turbidity of the culture at $660 \mathrm{~nm}$ was measured. As shown in Fig. 1A, TBT inhibited the growth of yeast cells. In the presence of 5 $\mu \mathrm{M}$ of TBT, however, about $10 \mathrm{hr}$ after addition of TBT, the turbidity of the culture started to increase. The duration of growth inhibition was related to the dose. With lower concentrations of TBT $(1 \mu \mathrm{M}$ and $2.5 \mu \mathrm{M})$, cells started to grow at earlier time point. In contrast, in the presence of $15 \mu \mathrm{M}$ of TBT, cells did not grow even at $20 \mathrm{hr}$ after addition of TBT. We examined the viability of cells in the presence of TBT by plate assay. The number of colonies grown on YPD, onto which TBT-treated or untreated yeast cells were spread, was counted. As shown in Fig. $1 \mathrm{~B}$, in the presence of $15 \mu \mathrm{M}$ of TBT, the number of colonies rapidly decreased. This is consistent with the induction of apoptosis as reported previously (Chahomchuen et al., 2009a). By contrast, with $5 \mu \mathrm{M}$ as well as the low- 


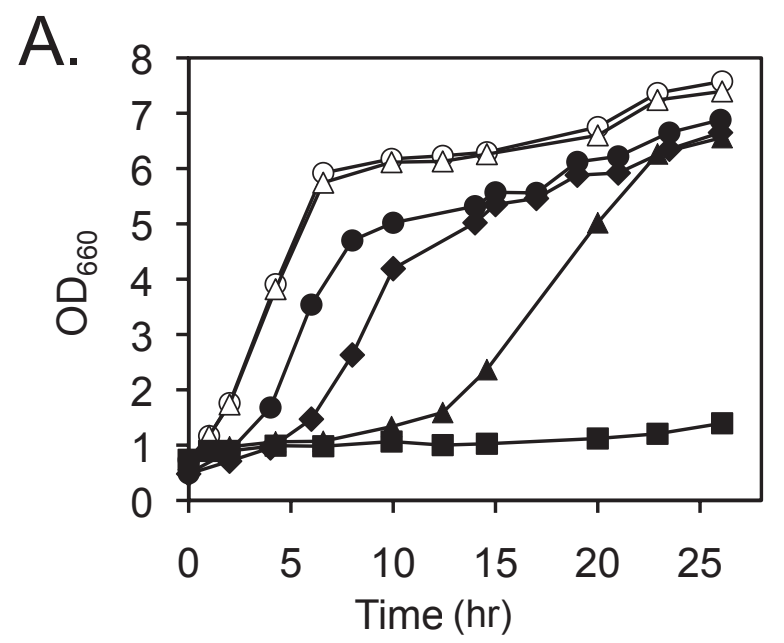

$$
\begin{array}{ll}
\hline \text { No addition } & \triangle+\mathrm{Me}_{2} \mathrm{SO} \\
\bullet+1 \mu \mathrm{M} \text { TBT } & \bullet+2.5 \mu \mathrm{M} \text { TBT } \\
\boldsymbol{\Delta}+5 \mu \mathrm{M} \text { TBT } & \mathbf{v}+15 \mu \mathrm{M} \text { TBT }
\end{array}
$$

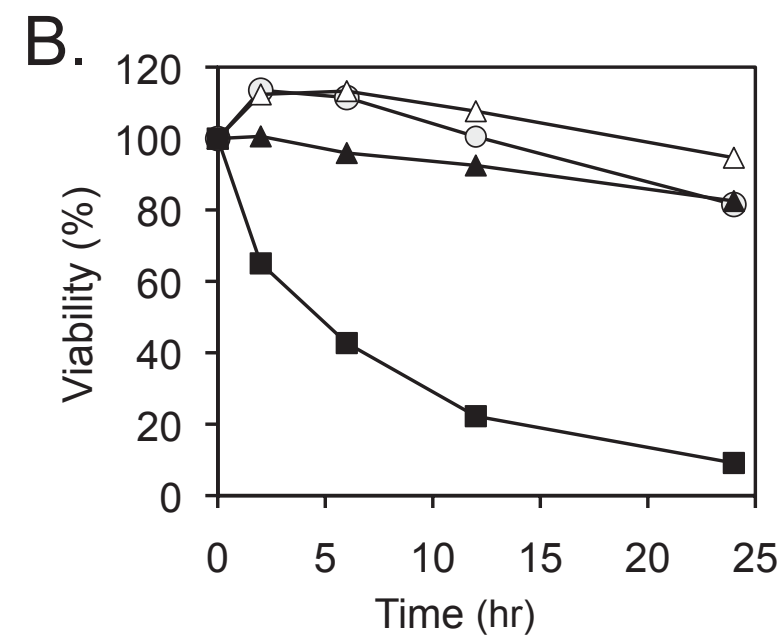

$$
\begin{array}{ll}
\text { O No addition } & \Delta+\mathrm{Me}_{2} \mathrm{SO} \\
\Delta+5 \mu \mathrm{M} \text { TBT } & \boldsymbol{\square}+15 \mu \mathrm{M} \text { TBT }
\end{array}
$$

Fig. 1. Effect of TBT on the growth and viability of yeast cells. (A) Yeast cells were grown in the absence or the presence of TBT in YPD medium. The growth of cells was measured by monitoring the optical density at $660 \mathrm{~nm}\left(\mathrm{OD}_{660}\right)$. Open circles, no addition; open triangles, $\mathrm{Me}_{2} \mathrm{SO}$ alone; closed circles, $1 \mu \mathrm{M}$ TBT; closed diamonds, $2.5 \mu \mathrm{M}$ TBT; closed triangles, $5 \mu \mathrm{M}$ TBT; closed squares, $15 \mu \mathrm{M}$ TBT. (B) S. cerevisiae cells were harvested at early logarithmic phase and treated with vehicle $\left(\mathrm{Me}_{2} \mathrm{SO}\right)$, or TBT at the concentration of $5 \mu \mathrm{M}$ or $15 \mu \mathrm{M}$. The same $\mathrm{OD}_{660}$ amount of cells was spread on YPD agar plate at indicated time point. Survival rates were calculated as the number of colonies grown after 3 days at $30^{\circ} \mathrm{C}$ relative to those at 0 hour, taken as $100 \%$. The results shown are the means of two independent experiments. Open circles, no addition; open triangles, $\mathrm{Me}_{2} \mathrm{SO}$ alone; closed triangles, $5 \mu \mathrm{M}$ TBT; closed squares, $15 \mu \mathrm{M} \mathrm{TBT}$.

er concentrations $(1 \mu \mathrm{M}$ and $2.5 \mu \mathrm{M})$ of TBT, the number of colonies grown on YPD plate did not decrease (Fig. $1 \mathrm{~B}$ and data not shown). These results indicate that cells maintain the viability, suggesting that low concentration of TBT induces cell cycle arrest.

To examine the effect of TBT on cell cycle, flow cytometric analysis of cell DNA content was performed. Logarithmically growing cells were transferred to fresh YPD containing $5 \mu \mathrm{M}$ TBT or the vehicle $\left(\mathrm{Me}_{2} \mathrm{SO}\right)$, and then collected for the analysis at each time point. When cultured in the absence of TBT, about 55-60\% of cells were constantly in the G1 phase (Fig. 2). After addition of TBT, however, the population of G1 phase cells significantly increased. About $75 \%$ of the cells were in the G1 phase after 6-12 hr, suggesting that TBT induces G1 arrest. To confirm this, cells were arrested at $\mathrm{M}$ phase by treating with the spindle poison nocodazole and subsequently released from the arrest by transferring to YPD without nocodazole. During nocodazole treatment, the population of cells with medium to large bud increased (Fig. 3), showing that metaphase to anaphase transition was blocked. After the release, in the absence of TBT, the populations of cells in G1 phase and in S/G2 phase that are with no and small bud, respectively, started to increase. On the other hand, in the presence of TBT, cells with no bud accumulated, whereas no increase of cells with buds was observed. We further examined the effect

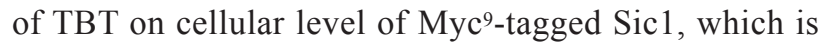
abundant in G1 phase cells (Schwob et al., 1994). As shown in Fig. 3B, at 100 min after the release from arrest by nocodazol treatment, Sic1-Myc ${ }^{9}$ level in the presence of TBT was increased to about three-fold of that in the absence of TBT. These confirm the notion that TBT blocks the G1 to $\mathrm{S}$ phase transition.

TBT has been shown to increase ROS production (Gennari et al., 2000). It has been shown that G1 arrest is induced by oxidative stress derived from ROS production (Flattery-O'Brien and Dawes, 1998; Chiu et al., 2011). 
T. Sekito et al.

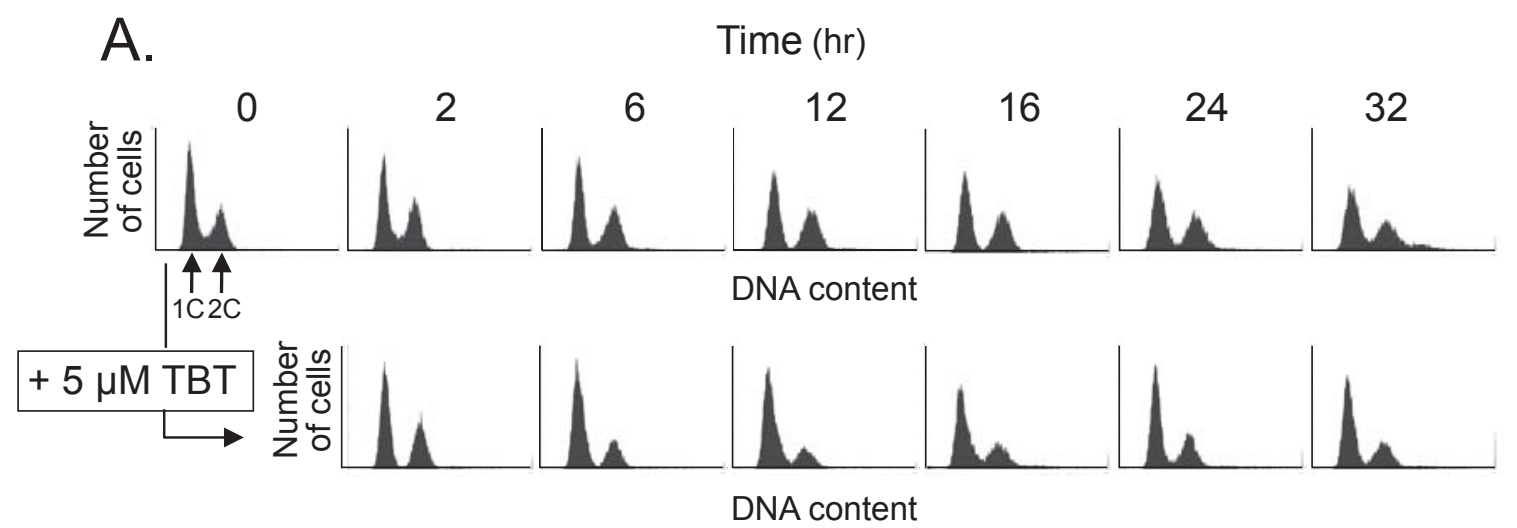

B.

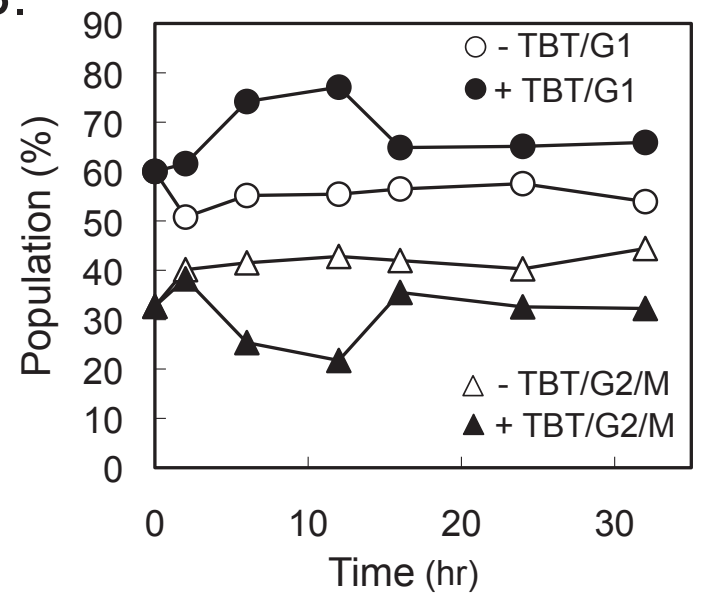

Fig. 2. Cellular DNA content distribution of TBT-treated and untreated cells. (A) Exponentially growing cells were transferred to fresh YPD medium containing vehicle $\left(\mathrm{Me}_{2} \mathrm{SO}\right)$ or $5 \mu \mathrm{M}$ TBT, and collected for flow cytometry analysis at each time point. (B) The percentage of cells found in the different phases of cell cycle by flow cytometry analysis was plotted on the graph. Open circles, -TBT/G1; closed circles, +TBT/G1; open triangles, -TBT/G2/M; closed triangles, +TBT/G2/M.

To test whether the growth arrest induced by TBT is due to increased ROS production, $N$-acetylcysteine (NAC), a ROS scavenger, was added to the culture containing TBT, and the effect on the growth was examined by measuring the $\mathrm{OD}_{660}$ of culture. Cells started to grow at $5 \mathrm{hr}$ after TBT addition in the presence of $2.5 \mathrm{mM}$ NAC, whereas in the absence of NAC, the growth was blocked until $10 \mathrm{hr}$ after the TBT addition (Fig. 4). This result indicates that NAC suppresses the growth inhibition induced by TBT, suggesting that ROS produced by TBT is at least a cause of the cell cycle arrest. In the presence of $5 \mathrm{mM}$ NAC, growth recovery started at earlier point. With higher concentration of NAC, $30 \mathrm{mM}$, howev- er, no further improvement on the growth recovery was observed (Fig. 4). Thus, improvement of growth recovery by NAC seems to be partial. Although this could be due to limitation of cellular uptake of NAC, it is also possible that TBT affects cell cycle progression through the distinct pathway(s) from ROS production. During the growth arrest for asynchronous cells in the presence of $5 \mu \mathrm{M}$ TBT, a certain population of cells was constantly in the stage other than G1 (Fig. 2). This shows the possibility that TBT blocks the cell cycle progression at other stage(s) in addition to G1 to S transition. In fact, after releasing cells synchronized in $\mathrm{S}$ phase by using hydroxyurea, appearance of cells without bud that is in G1 
A.
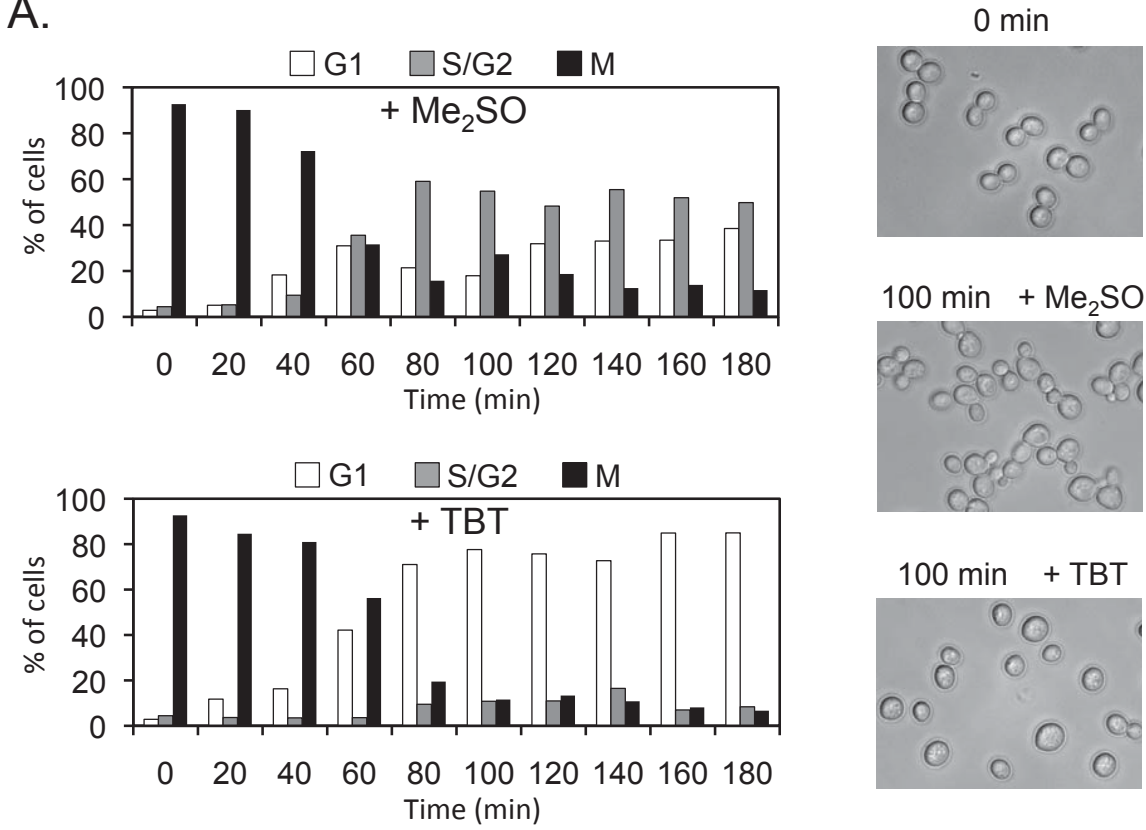

B.

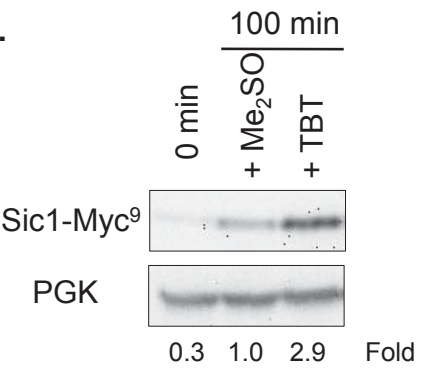

Fig. 3. Cell cycle progression after release from nocodazole synchronization. (A) Percentage of budded cells in nocodazole-synchronized cultures that were vehicle-treated $\left(\mathrm{Me}_{2} \mathrm{SO}\right)$ or TBT-treated was plotted. Cells were released from G2/M arrest induced by nocodazole at $0 \mathrm{~min}$. The budding status of at least 150 cells from each time point was visually determined using a Olympus IX81 microscope with a $40 \times$ phase contrast objective. Percentage of G1 (unbudded cell, white bar), S + G2 (cell with small bud, gray bar), M phase (cell with large bud, black bar) was counted. The results shown are the means of two independent experiments. Representative cell images at $0 \mathrm{~min}$ and $100 \mathrm{~min}$ after the release from G2/M arrest in the presence of vehicle $\left(\mathrm{Me}_{2} \mathrm{SO}\right)$ or TBT were indicated at the right. (B) Whole cell extracts were prepared from cells arrested at G2/M by nocodazole $(0 \mathrm{~min})$ or cultured for $100 \mathrm{~min}$ in the presence of vehicle $\left(\mathrm{Me}_{2} \mathrm{SO}\right)$ or TBT after release from the arrest, and analyzed by Western blotting using anti-Myc and anti-PGK antibodies. The intensity of Sic1-Myc ${ }^{9}$ band normalized to PGK loading control is expressed as fold increase at the bottom.

was obviously delayed in the presence of TBT (data not shown), showing that the progression of cell cycle from $\mathrm{S} /$ G2 to G1 thorough M phase was inhibited by TBT. ROS production results in DNA damage and subsequent repair response, which may lead to cell cycle arrest at various stages such as G1, S and G2 phases. TBT also increases plasma membrane permeability toward $\mathrm{Ca}^{2+}$ (Aw et al., 1990; Stridh et al., 1999). Rapid increase of $\mathrm{Ca}^{2+}$ concentration induces G2 delay (Mizunuma et al., 1998). The relationship between the changes in cellular $\mathrm{Ca}^{2+}$ concentration induced by TBT treatment and cell cycle progression is now under investigation. As TBT, formic acid was reported to induce the generation of ROS and cell death in S. cerevisiae cells. However, unlike TBT-induced cell death, which depends on the caspase orthologue Yca1 (Chahomchuen et al., 2009a), formic acid triggers cell death through Ycal-independent pathway (Du et al., 2008). We examined the effect of formic acid on the cell 


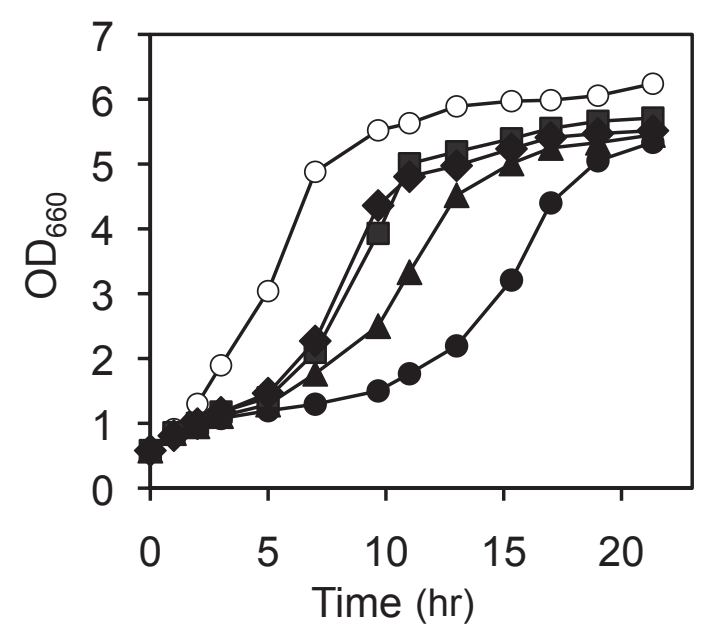

\begin{tabular}{|l|}
\hline O No addition \\
$-+5 \mu \mathrm{M}$ TBT \\
$\mathbf{\Delta}+5 \mu \mathrm{M}$ TBT, $2.5 \mathrm{mM}$ NAC \\
$\mathbf{\square}+5 \mu \mathrm{M}$ TBT, 5 mM NAC \\
$+5 \mu \mathrm{M}$ TBT, $30 \mathrm{mM}$ NAC
\end{tabular}

Fig. 4. $N$-acetylcysteine suppresses the growth arrest induced by TBT treatment. Yeast cells exponentially growing at $30^{\circ} \mathrm{C}$ were split into aliquots, treated with $5 \mu \mathrm{M}$ TBT and/or various concentrations of $N$-acetylcysteine (NAC). As a control of TBT treatment, cells were cultured in the presence of vehicle $\left(\mathrm{Me}_{2} \mathrm{SO}\right)$. The growth of cultures was measured by monitoring the $\mathrm{OD}_{660}$. Open circles, $\mathrm{Me}_{2} \mathrm{SO}$ alone; closed circles, $5 \mu \mathrm{M}$ TBT; closed triangles, $5 \mu \mathrm{M}$ TBT $+2.5 \mathrm{mM} \mathrm{NAC}$; closed squares, $5 \mu \mathrm{M}$ TBT $+5 \mathrm{mM}$ NAC; closed diamonds, $5 \mu \mathrm{M}$ TBT $+30 \mathrm{mM}$ NAC.

growth and viability. While TBT-treatment decreased the growth but not the viability (Fig. 1), with increasing concentration of formic acid, cell viability concurrently decreased with the growth (data not shown). In addition, we could not detect the growth recovery during prolonged culture in the presence of formic acid at $40 \mathrm{mM}$, the minimum concentration to block the growth. These implicate that the growth retardation with formic acid might not be due to cell cycle arrest but rather reflect the cell death. It is likely that the pleiotropic toxicity of these compounds leads to such variation of effects on cell growth and/or cell death processes. S. cerevisiae will serve as a useful organism to unravel the mechanisms underlying toxicity of TBT and other toxic compounds.

\section{ACKNOWLEDGMENTS}

We thank Y. Kamada, National Institute for Basic Biology, for helpful discussion and Kana Hondo, Ehime University, for technical assistance. This work was supported by Global COE Program "Interdisciplinary Studies on Environmental Chemistry" (to Ehime University) by the Ministry of Education, Culture, Sports, Science, and Technology (MEXT), Japan, and a grant-in-aid from Elizabeth Arnold Fuji Foundation (to Y.K. and T.S.) and from the Noda Science Foundation (to Y.K. and T.S.).

\section{REFERENCES}

Alzieu, C.L., Sanjuan, J., Deltreil, J.P. and Borel, M. (1986): Tin contamination in Arcachon Bay: Effects on oyster shell anomalies. Mar. Pollut. Bull., 17, 494-498.

Antizar-Ladislao, B. (2008): Environmental levels, toxicity and human exposure to tributyltin (TBT)-contaminated marine environment. a review. Environ. Int., 34, 292-308.

Aw, T.Y., Nicotera, P., Manzo, L. and Orrenius, S. (1990): Tributyltin stimulates apoptosis in rat thymocytes. Arch. Biochem. Biophys., 283, 46-50.

Beaumont, A.R. and Budd, M.D. (1984): High mortality of the larvae of the common mussel at low concentration of tributyltin. Mar. Pollut. Bull., 15, 402-405.

Chahomchuen, T., Akiyama, K., Sekito, T., Sugimoto, N., Okabe, M., Nishimoto, S., Sugahara, T. and Kakinuma, Y. (2009a): Tributyltin induces Ycalp-dependent cell death of yeast Saccharomyces cerevisiae. J. Toxicol. Sci., 34, 541-545.

Chahomchuen, T., Hondo, K., Ohsaki, M., Sekito, T. and Kakinuma, Y. (2009b): Evidence for Avt6 as a vacuolar exporter of acidic amino acids in Saccharomyces cerevisiae cells. J. Gen. Appl. Microbiol., 55, 409-417.

Chiu, J., Tactacan, C.M., Tan, S.X., Lin, R.C., Wouters, M.A. and Dawes, I.W. (2011): Cell cycle sensing of oxidative stress in Saccharomyces cerevisiae by oxidation of a specific cysteine residue in the transcription factor Swi6p. J. Biol. Chem., 286, 5204-5214.

Davies, I.M., Harding, M.J.C., Bailey, S.K., Shanks, A.M. and Lange, R. (1997): Sublethal effects of tributyltin oxide on the dogwhelk Nucella lapillus. Mar. Ecol. Prog. Ser., 158, 191-204.

Du, L., Su, Y., Sun, D., Zhu, W., Wang, J., Zhuang, X., Zhou, S. and Lu, Y. (2008): Formic acid induces Ycalp-independent apoptosis-like cell death in the yeast Saccharomyces cerevisiae. FEMS Yeast Res., 8, 531-539.

Dyrynda, E.A. (1992): Incidence of abnormal shell thickening in the Pacific oyster Crassostrea gigas in Poole Harbour (UK), subsequent to the 1987 TBT restrictions. Mar. Pollut. Bull., 24, 156163.

Flattery-O'Brien, J.A. and Dawes, I.W. (1998): Hydrogen peroxide causes RAD9-dependent cell cycle arrest in G2 in Saccharomyces cerevisiae whereas menadione causes $\mathrm{G}_{1}$ arrest independent of RAD9 function. J. Biol. Chem., 273, 8564-8571.

Gennari, A., Viviani, B., Galli, C.L., Marinovich, M., Pieters, R. and Corsini, E. (2000): Organotins induce apoptosis by disturbance of $\left[\mathrm{Ca}^{2+}\right]_{\mathrm{i}}$ and mitochondrial activity, causing oxidative stress and activation of caspases in rat thymocytes. Toxicol. Appl. Pharmacol., 169, 185-190. 
Yeast cell cycle arrest by tributyltin

Haase, S.B. and Lew, D.J. (1997):Flow cytometric analysis of DNA content in budding yeast. Methods Enzymol., 283, 322-332.

Iwata, H., Tanabe, S., Mizuno, T. and Tatsukawa, R. (1995): High accumulation of toxic butyltins in marine mammals from Japanese coastal waters. Environ. Sci. Technol., 29, 2959-2962.

Kawanishi, T., Asoh, H., Kato, T., Uneyama, C., Toyoda, K., Teshima, R., Ikebuchi, H., Ohata, H., Momose, K., Hayakawa, T. and Takahashi, M. (1999): Suppression of calcium oscillation by trin-butyltin chloride in cultured rat hepatocytes. Toxicol. Appl. Pharmacol., 155, 54-61.

Kotake, Y. (2012): Molecular mechanisms of environmental organotin toxicity in mammals. Biol. Pharm. Bull., 35, 1876-1880.

Mizunuma, M., Hirata, D., Miyahara, K., Tsuchiya, E. and Miyakawa, T. (1998): Role of calcineurin and Mpk1 in regulating the onset of mitosis in budding yeast. Nature, 392, 303-306.

Oliver, S.L., Joseph, J.C. and Geoffrey, M.G. (1989): Toxicity of organotins towards the marine yeast Debaryomyces hansenii. Microb. Ecol., 17, 275-285.

Raffray, M. and Cohen, G.M. (1993): Thymocyte apoptosis as a mechanism for tributyltin-induced thymic atrophy in vivo. Arch. Toxicol., 67, 231-236.

Reader, S., Moutardier, V. and Denizeau, F. (1999): Tributyltin triggers apoptosis in trout hepatocytes: the role of $\mathrm{Ca}^{2+}$, protein kinase $\mathrm{C}$ and proteases. Biochim. Biophys. Acta., 1448, 473 485.

Schwob, E., Böhm, T., Mendenhall, M.D. and Nasmyth, K. (1994): The B-type cyclin kinase inhibitor $\mathrm{p} 40^{\text {sIC } 1}$ controls the G1 to $\mathrm{S}$ transition in S. cerevisiae. Cell, 79, 233-244.

Stridh, H., Gigliotti, D., Orrenius, S. and Cotgreave, I. (1999): The role of calcium in pre- and postmitochondrial events in tributyltin-induced T-cell apoptosis. Biochem. Biophys. Res. Commun., 266, 460-465.

Tanabe, S. (1999): Butyltin contamination in marine mammals - a review. Mar. Pollut. Bull., 39, 62-72.

Thompson, T.A., Lewis, J.M., Dejneka, N.S., Severs, W.B., Polavarapu, R., and Billingsley, M.L. (1996): Induction of apoptosis by organotin compounds in vitro: neuronal protection with antisense oligonucleotides directed against stannin. J. Pharmacol. Exp. Ther., 276, 1201-1216.

Veiga, A., Pinto, A.F. and Loureiro-Dias, M.C. (1997): Tributyltin oxide affects energy production in the yeast Rhodotorula ferulica, a utilizer of phenolic compounds. Can. J. Microbiol., 43, 683-687.

White, J.S. and Tobin, J.M. (2004): Inorganic tin and organotin interactions with Candida maltosa. Appl. Microbiol. Biotechnol., 63, 445-451. 